\title{
A prágai tavasz eltiprása és a Nagykürtösi járás
}

\author{
Miskei Ferenc
}

The Suppression of the Prague Spring and the Vel'ký Krtíš District Abstract

The Vel'ký Krtís District was established in 1968 during the 'free air' of the Prague Spring when the Czechoslovak National Assembly issued a command on the unification of eight municipalities of the Zvolen District and the western part of the Lučenec District. Its establishment was primarily in accordance with the intentions of the state to help this economically underdeveloped region. The leaders of this new administrative unit had to face several challenges in 1968: firstly, they were expected to build all means of infrastructure of the new district; secondly, they had to solve the problems caused by the Warsaw Pact invasion of Czechoslovakia during which the Hungarian People's Army occupied this area.

Keywords: Czechoslovakia; Prague Spring; occupation; Hungarian People's Army; Vel'ký Krtíš District

Kulcsszavak: Csehszlovákia; prágai tavasz; megszállás; Magyar Néphadsereg; Nagykürtösi járás

Subject-Affiliation in New CEEOL: History - Recent Histoty - Post-War Period

DOI: 10.36007/eruedu.2021.3.060-075

\section{Csehszlovákia és a prágai tavasz ${ }^{1}$}

Az 1956-os magyar és lengyel reformkommunista mozgalmak után bő egy évtizeddel Csehszlovákiában 1968-ban szintén egyfajta demokratikus szocialista mozgalom bontakozott ki annak reményében, hogy az Antonín Novotný nevével fémjelzett és a magát mereven tartó sztálinista típusú diktatúrát próbálja meg változásokra, újításokra ösztönözni. Az, ami 1968-ban Csehszlovákiában történt, több okra vezethető vissza, s javarészt a hatalmon lévő politikai elit elhibázott döntéseinek következménye volt (Berend 1999, 172).

A hatvanas évek első felében például összeomlott az ötéves terv a mennyiség a minőség rovására történő eröltetése következtében, az ebből kialakuló gazdasági pangás pedig a társadalomban is éreztette hatását. Ugyan az állam korlátozott reformjaival próbált úrrá lenni az általános elégedetlenségen, de azok nem igazán váltak be. Némi előrelépést ugyan hozott az 1962-ben megalakult Kolder-bizottság, mely az ötvenes évek koncepciós pereinek ismételt felülvizsgálata során megállapította, hogy több ítélet született meg kierőszakolt vallomások, hamis bizonyitékok alapján. Ennek eredményeképpen ugyan pár kompromittálódott állami vezető (pl.

1 Jelen tanulmány alapjául a szerző azonos témában írt diplomamunkája szolgált, amelyet 2021 nyarán védett meg az SJE Tanárképző Kar Történelem Tanszékén. A hallgató a szakdolgozatáért és a tanulmányai alatt mutatott kiváló teljesítményéért dékáni dícséretben részesült. 
Karol Bacilek, Viliam Široký) távozásra kényszerült, de összességében a politikai klíma érdemben nem változott meg. Mindezen tényezők egyre nagyobb feszültséghez vezettek a társadalomban, mígnem a Csehszlovákia Kommunista Pártja Központi Bizottsága Alexander Dubčekkal az élén 1968. január 5-én fel nem lázadt Novotný ellen, s követelte annak lemondását (Pataky 2008, 8-10).

A párt Központi Bizottsága 1968. január 5-i ülésén Novotný az őt és politikáját ért heves támadások következtében kénytelen volt lemondani a pártban betöltött első titkári posztjáról, s helyére Alexander Dubček lett megválasztva (Berend 1999, 175). A reformerek (pl. Ota Šik, Oldřich Černík, Josef Smrkovský) hatalomba történő fokozatos beemelése következtében április 1-jén látott napvilágot a párt új Akcióprogramja, amely kimondta, hogy az országban a szocializmus eltorzított modelljét vezették be, amelyet reformokkal szükséges kijavítani, orvosolni. A program szerint egyik párt sem monopolizálhatja a szocialista államhatalmat, s szerintük a szocializmusnak éppen a demokrácia és a polgári szabadságjogok elmélyítésével kell igazolnia, hogy túltesz a nyugati, „burzsoá” demokráciákon (Bencsik 2016, 320-321).

Az 1968 áprilisától augusztusig tartó időszakot nevezi a szakirodalom prágai tavasznak, mely során a csehszlovák reformorientált vezetés megkísérelte bevezetni az „emberarcú szocializmust”, amely olyan reformokban manifesztálódott, mint a sajtócenzúra eltörlése (Vajda 2016; Vajda 2017, 47-49), a szólásszabadság bővülése, a piacgazdaság pozitiv megítélése. Mindezekkel párhuzamosan a csehszlovák társadalom is egyre jobban pluralizálódni kezdett: független ellenzéki csoportosulások alakultak, mint amilyen a K 231 (politikai üldözöttek csoportja), vagy a KAN (Klub angažovaných nestraníků - Elkötelezett Pártonkívüliek Klubja) is voltak.

\section{Kádár János és a Magyar Néphadsereg Csehszlovákia kato- nai megszállásában játszott szerepe}

A Csehszlovákiában tapasztalható jelenségek a többi szocialista ország nemtetszését és félelmét is kiváltották. Aggodalmaik szerint az országban aktivizálódott a ,jobboldal”, valamint „ellenforradalmi tendenciák” jelentek meg, s ez rájuk is veszélyt jelent. A csehszlovák pártvezetés és az „elégedetlenkedő” keleti blokkbéli országok vezetői között a Magyar Népköztársaság de facto első embere, Kádár János próbált meg egyfajta közvetítőszerepet betölteni: a szocialista pártok 1968. márciusi drezdai és májusi moszkvai értekezletein Kádár kiállt a csehszlovák reformok szükségessége mellett, mondván, hogy azok a sokévnyi rossz politikai döntés helyrehozatalát célozzák meg, és szigorúan Csehszlovákia belügyét képezik (Békés 2008, 195).

Ugyanakkor a csehszlovák sajtócenzúra eltörlésével Kádárt is támadó cikkek láttak napvilágot, de a legnagyobb felháborodást Ludvík Vaculík június 27-i 2000 szó című publikációja váltotta ki, mely polgári engedetlenséget is kilátásba helyezett a reformok megvédése érdekében (Bencsik 2016, 329). Ilyen körülmények közt került sor a szocialista pártok júniusi varsói értekezletére, ahol Kádár már kényte- 
len volt feladni eredeti álláspontját, és Moszkva iránti feltétlen hüségét hangoztatva elfogadta a Szovjetunió Csehszlovákia elleni katonai intervenciójában a részvételt (Mitrovits 2018, 433). Ez után került sor az augusztus 3-i pozsonyi találkozóra: a szocialista tömb egységét demonstrálni akaró szovjet pártfötitkár, Brezsnyev nyilatkozatot fogadtatott el a szocialista országokkal: a nyilatkozat leszögezte, hogy a „,szocialista vívmányok védelme az összes szocialista állam internacionalista kötelessége". Ez a kijelentés vált a tételmondatává a szocialista országok korlátozott szuverenitását meghirdető ún. Brezsnyev-doktrínának (Vajda 2020, 54). A pozsonyi találkozó keretében juttatták el a csehszlovák reformellenes pártvezetők, az ún. „egészséges erők” (pl. Vasil Bil'ak, Alois Indra, Jiři Kolder) a szovjetekhez az ún. behívólevelet is, természetesen titokban (Kořinek 2006, 82-83).

K. I. Provalov vezérezredes, a Magyarországon állomásozó szovjet Déli Hadseregcsoport parancsnoka már 1968. április 8-án megkapta Grecsko marsall, a Szovjetunió honvédelmi miniszterének iránymutatásait a Déli Hadseregcsoport Csehszlovákia megszállásában végrehajtandó feladataira vonatkozóan (Jagadics 2018, 19). A parancs értelmében egy magyar hadosztálynak kellett részt venni a hadműveletben. A választás a Magyar Néphadsereg egyik legjobban felszerelt alakulatára esett, mégpedig a zalaegerszegi 8. gépkocsizó lövészhadosztályra, amit később kiegészítettek a Nógrád megyebéli rétsági 31. harckocsiezreddel is (Horváth 2001, 232). A kijelölt egységeket Zala megyéböl nagy precizitással átcsoportosították Nógrád megyei várakozási körleteikbe, ahonnét kiindulva 1968. augusztus 22-án 24:00-kor három ponton lépték át a csehszlovák-magyar államhatárt (konkrétan a Balassagyarmat-Tótgyarmat, a Parassapuszta-Ipolyság és a Letkés-Ipolyszalka átkelökön), hogy a Magyar Néphadsereg fennállása során egyetlen „éles bevetésének” résztvevőivé váljanak.

\section{A prágai tavasz és a Nagykürtösi járás}

\subsection{Az új járás gazdasági mutatói}

Az 1960. július 1-jén életbe lépő csehszlovák közigazgatási reform alapján, melyet a csehszlovák Nemzetgyülés 1960. április 9-én mint 36/1960. sz. törvényt fogadott el, Szlovákiát a közigazgatás szempontjából három kerületre osztották fel, és a járások számát is kilencvenhétröl mindössze harmincháromra csökkentették (Popély 2006, 236). A megszüntetett (köztük sok magyarlakta) járások közt a Kékkői is szerepelt, amelynek területét javarészt a Losonci járásba olvasztották be, jelentősen növelve annak területi kiterjedését, és amelyhez így több mint százötven település tartozott. A területi átszervezést gazdasági szempontokkal indokolták: a megnövelt területű járás szervezői iparfejlesztést, általános gazdasági fellendülést ígértek. Ugyanakkor e közigazgatási reform eredményeképpen a gazdasági és kulturális élet mindinkább visszaesett, hiszen a föbb befektetéseket továbbra is Losonc városa és környéke szívta fel. ${ }^{2}$

2 Új Szó, 1968. augusztus 4. 7. 
A térség e kedvezőtlen közigazgatási beosztása nyolc év után változott meg ismét, mikor is a csehszlovák kormány - a közép- és a kelet-szlovákiai kerületi nemzeti bizottságok javaslatára ${ }^{3}$ - 1968. február 28-án kiadta a 36/1968. sz. rendeletét négy új járás létrehozásáról. Így a Varannói, Vízközi és Ólublói járások mellett negyedikként megalakult 1968. július 1-jén a Nagykürtösi is (Popély 2006, 269). Ez utóbbi a besztercebányai székhelyü Közép-szlovákiai Kerület tizenharmadik járása lett. Az új járáshoz visszacsatolták az egykori Kékkői járás szinte mindegyik községét, sőt - regionális és történelmi okokra hivatkozva - további nyolc községet is hozzácsatoltak a töle északra található Zólyomi járásból. Az új járás így 873,5 km² kiterjedésü területtel rendelkezett, területén összesen 74 községben 47 ezer lakos élt: kétharmaduk szlovák, míg egyharmaduk magyar nemzetiségű volt, s közülük 13600 személy volt gazdaságilag aktív. ${ }^{4}$

A térség állami iparosítása a hatvanas évek elején kezdődött meg, de Nagykürtös és térsége - Losonc előbb emlitett erősebb „,szívóerejének” köszönhetően - szinte teljes egészében kimaradt a folyamatból, hiszen az új közigazgatási egység megalakulásakor az összlakosság mindössze 4,8\%-a, azaz 2270 ember dolgozott az iparban, míg e szférában az állami átlag 17,8\% volt. Mindenesetre a járás egyöntetü mezőgazdasági jellege megmutatkozott az ott foglalkoztatott munkaerö nagyságában is: körülbelül 8360 személy dolgozott abban a szektorban, s itt hajtották végre a legtöbb modernizációt is. Végül a szolgáltatói szektor 2970 fönyi munkaerőt tudott foglalkoztatni. ${ }^{5}$

E kevésbé kedvező körülmények következtében sok környékbéli a szomszédos járásokban dolgozott, mint amilyen a Losonci járás is volt. Volt ugyan a járásnak egy saját péksége, egy, körülbelül háromszáz női alkalmazottnak munkát adó konfekciós üzeme, valamint említésre méltó még a zsélyi Kovohron üzem. Megemlítendő a járás barnaszénbányája (a Baňa Dolina), amely akkor 1700 embert foglalkoztatott, de az nem tudott mindenkinek munkát adni, valamint hiányzott a megfelelö infrastruktúra: a járásban nem volt egyáltalán vasút. ${ }^{6} \mathrm{Ez}$ több problémát is magában hordozott. Egyfelöl vasút híján nem érkeztek ipari befektetések a környékre, másrészt a már meglévő, mindössze nyolc kilométeres vasúti szakaszt sem látták központilag érdemesnek a további kiépítésre, hiszen - nem lévén ipari üzem - feleslegesnek itélték. Ugyan a mezőgazdasági munkák idényszerüen sok embernek munkát adtak, de azok sem bizonyultak tartós megoldásnak. ${ }^{7}$

\subsection{A járási szervek tevékenysége a katonai megszállásig}

Az új járás valamennyi szervének (pl. járási nemzeti bizottság, a kommunista párt járási bizottsága, stb.) a „legelejéröl” kellett kezdeni a munkát, lényegében nekik kellett megszervezni az új közigazgatási egység infrastruktúráját. Már 1968 februárjában a Nagykürtösi Városi Nemzeti Bizottság plenáris ülésén megtárgyalták az egyes járási szervek elhelyezését: a megbeszélésen arra a döntésre jutottak, hogy

3 Új Szó, 1968. március 1. 2.

4 Smer, 1968. április 18. 3.

5 Smer, 1968. április 18. 3.

6 Smer, 1968. április 18. 3.

7 Smer, 1968. április 18. 3. 
hatvanhárom helyiséget biztosítanak a városban az új járás adminisztratív szerveinek részére. ${ }^{8}$

Bár közigazgatási szempontból 1968. július 1-ig még a Losonci járáshoz tartozott, már március 16-án megkezdődött Szlovákia Kommunista Pártja Járási Bizottságának kétnapos alakuló közgyülése, amelyen 172 delegált vett részt. ${ }^{9}$ Az értekezleten Csehszlovákia Kommunista Pártja (CSKP) Központi Bizottságát Ondrej Klokoč és Dénes Ferenc (aki egyben az Új Szó főszerkesztője is volt) képviselte. A gyülés a CSKP megújhodásának szellemében zajlott, ugyanis az egyes beszámolókat, felszólalásokat heves taps szakította félbe: a résztvevők teljes nyiltsággal beszéltek az őket is érintő problémákról, többek közt Szlovákia Kommunista Pártja (SZLKP) Losonci Járási Bizottsága vezetése is éles kritikát kapott a Nagykürtösi járásbéli állapotokért. Támogatásukat fejezték ki a CSKP KB januári plénumán kijelölt „új iránynak", s Zoltán Pal'kot választották a járási bizottság vezető titkárává. ${ }^{10} \mathrm{~A}$ résztvevők szerint a demokratizálási folyamat egyúttal iparosítást is jelentene a Nagykürtösi járásban. ${ }^{11}$ Egyúttal szerették volna elérni, hogy a járást a kevésbé fejlett területek közé sorolják be, ami megkönnyítené annak ipari fejlesztését.

A többi járási szerv azonban jóval késöbb alakult meg. Zsélyi Nagy Lajos A Hét tudósítójaként például 1968 júniusában járt Nagykürtösön. Az új Járási Nemzeti Bizottságot kereste, de a már korábban megalakult járási pártszervezet vezető titkára a tudtára adta, hogy az csak a választások után fog a városba költözni. ${ }^{12}$ Június 29-én a SZLKP JB rendkívüli gyülésén a demokratizálási folyamat aktuális eredményeiröl folytattak megbeszélést, majd sok résztvevő felszólalt, hogy a járási pártszervezeten kívül nincs más járási szerv Nagykürtösön, egyúttal sürgették azok megalakulását, hiszen így a járási akcióprogramot sem lehetett elfogadni. Végül támogatásukról biztosították a CSKP KB politikáját, majd elítélték a 2000 szó címü publikációt. ${ }^{13}$

A Nagykürtösi Járási Nemzeti Bizottság végül július 31-én tartotta meg alakuló közgyülését, ahol egyhangúlag megválasztották a szervezet tanácsát, annak elnökét Ján Jarabka személyében, valamint az egyes albizottságok elnökeit is. A gyűlés végén annak eredményeiröl értesitést küldtek a felettes szerveknek, melyben a CSKP KB reformprogramja melletti kiállásukat hangsúlyozták. ${ }^{14}$

\subsection{A járás katonai megszállása}

A Nagykürtösi járásnak csupán egy jelentősebb határátkelöhelye van Magyarországgal: a csaknem százöt méter hosszú Ipoly-híd csehszlovák oldalról Tótgyarmat községet köti össze a magyarországi Balassagyarmat városával. Ez a turizmus szempontjából is egy igen frekventált határátkelő volt, hiszen 1968 nyári hónapjai-

8 Új Szó, 1968. február 10. 2.

9 Smer, 1968. március 17. 1.

10 Smer, 1968. március 18. 1.

11 Új Szó, 1968. március 21. 5.

12 Vö. A Hét, 1968. június 2. 6-7.

13 Uo. 2.

14 Smer, 1968. augusztus 1. 1. 
ban is csaknem ezer turista haladt át rajta naponta - ezért pár turisztikai ügynökség irodát is nyitott a határátkelő épületében.

A Duna-hadmüvelet keretében a balassagyarmati határörök - mint minden érintett határszakaszon - az akció megkezdése elött itt is lefegyverezték a csehszlovák határör-kollégáikat augusztus 20-án 24:00-ig, majd a Magyar Néphadsereg egységei áttörték a határsorompókat és átlépték az államhatárt. Egyedüli ellenállást csupán az ipolyhídvégi határörs egyik magyar nemzetiségü csendöre tanúsított, aki nem volt hajlandó leadni fegyverét és szökni próbált. Az egyik magyar katona kénytelen volt a fegyverét használni, mire mindkét csehszlovák csendör megadta magát - az egyik könnyebben megsebesült (Pataky 2008, 95-96). Másnap csaknem 350, többségében lengyel turista személygépkocsija torlódott fel a csehszlovák oldalon a határzárnak köszönhetően, $s$ az ellátásuk is problémás volt. ${ }^{15}$

Az egységek a kijelölt 1. számú hadműveleti útvonalon (Balassagyarmat - Apátújfalu - Csáb - Litva - Szénavár - Bozók - Hontnémeti stb.) szelték át a járás területét, hogy végső célként elérjék és birtokukba vegyék Vágújhelyet és Nagytapolcsányt; tehát Nagykürtöst még nem ezek az egységek vették birtokukba. A járás területén a szovjet és magyar vezetés számított némi csehszlovák katonai ellenállásra: az Oremov Laz megnevezésű csehszlovák katonai gyakorlótér (mai neve Vojenský obvod Lešt') egységei ugyanakkor semmilyen ellenállást sem tanúsítottak (M. Szabó 2019, 190-191). A hadműveleti útvonal mentén található községek lakosai - legalábbis Csábon - augusztus 21-ének hajnalán a vonuló magyar tankok keltette zajra riadtak fel. A helyiek másnap reggel már katonákat szállító teherautókat láttak keresztülmenni a községen. Pár falubéli integetett is a katonáknak, akik szintén intéssel viszonozták a „köszöntést”. ${ }^{16}$ Ugyanitt a tankok vonulása következtében jelentős anyagi kár keletkezett: több falubéli birtok kerítését megrongálták, továbbá a helyi hangosbemondó-rendszerben is kár keletkezett. ${ }^{17}$

A Parassapuszta-Ipolyság-határátkelőnél kezdődő 2. számú hadműveleti útvonalon az elörenyomuló magyar egységek elsőrendü feladata Léva városának két hadosztállyal történő gyors elfoglalása volt. Időközben viszont a menetoszlopról Felsőszemerédnél a 31. hk. ezred 1. hk. zászlóalja Hábel Péter és Pense István vezetésével jobbra levált az ezred fő erőitől, majd innét önálló menettel a PalástCsáb-Alsópalojta útvonalon érte el és szállta meg Nagykürtöst (Homor 2010, 93). A járási székhelyre augusztus 21-én, délután 14:00-kor érkeztek meg és 16:00-ra befejezték annak megszállását. Már a megérkezésükkor több, az úttest aszfaltburkolatára festett nagyméretű felirat várta öket: „Gyarmat 13 km”, illetve „Okupanti domov!" (Végh 2008, 36-37).

A járás és a város vezetői tiltakoztak bár, de hajlandók voltak az együttműködésre: ennek köszönhetően még aznap este 22:00-kor a Magyar Néphadsereg egységei bevonták az operatív ellenőrző csoportjaikat a városi vasútállomásról, a Járási Nemzeti Bizottság székházából, valamint a helyi pártbizottság épületéböl (Csík 2018, 56-57). A JNB épületében ugyanakkor két helyiséget lefoglaltak ma-

15 ŠABB-PVK, f. OV KSS VK, ZPr 1968, Zápisnica zo zasadnutia Predsedníctva OV KSS vo VK, 21.23. august $1968,3$.

16 Interjú Miskei Margit csábi lakossal, 2020. december 1.

17 ŠABB-PVK, f. Spisy 1968, č. 227/1968, Rada MNV v Čebovciach: Nahlásenie škôd, ktoré spravili vojaci Varšavskej zmluvy, 3. september 1968. 
guknak, továbbá a helyi posta épületét is megszállva tartották. ${ }^{18} \mathrm{~A}$ városi nemzeti bizottság épületében is szerettek volna helyiségeket „,bérelni”, de a szerv a kérésüket egyhangúlag visszautasította. ${ }^{19}$ Rögtön a megszállás napján kisebb tömeg verödött össze város evangélikus templomának közelében, s szidalmazta a város melletti dombon „,sátrat verő” katonákat. Azon lakosok, akik tudtak magyarul, szóba elegyedtek a katonákkal, akik azt próbálták nekik megmagyarázni, hogy miért jöttek (Aláč 2020, 59). Az egyik tiszt a helyi alapiskola igazgatóhelyettesét kérte meg az elszállásolásuk megoldására: az egyik, még épülőfélben lévő alapiskola szemügyre vétele után - mivel annak valamennyi osztálytermében csupán betonalap volt - inkább maradtak a város határában elterülő domboldalon felépített sátortáborukban. A biztonság kedvéért, egyúttal figyelmeztetésül, a katonák a tankok lövegeit a város felé irányították. ${ }^{20}$

A következő nap, augusztus 22-e a vidék megszállásának a jegyében telt: körzetparancsnokságokat küldtek ki a járás jelentősebb településeire, mint amilyenek Csáb és Szénavár községek is voltak. A lakosság valamennyi helyen ellenkezve fogadta őket, de incidensre sehol sem került sor, a helyzet a járás valamennyi községében mindvégig nyugodt maradt.

\subsection{A járás a katonai megszállás ideje alatt}

A SZLKP Járási Bizottságának elnöksége a megszállás első napjától egészen augusztus 23-ig folyamatosan ülésezett, s 22-én tiltakozó jegyzéket küldött szét a megszállásban részt vevő országok nagykövetségei számára. A gyülésen szó esett arról, hogy a lakosság nagy számban vásárolta fel az alapvető élelmiszereket, valamint problémaként hozták fel a helyi szénbányából kitermelt barnaszén szállításának megszünését is, ugyanis a szállításra szolgáló vasúti pálya a Magyar Népköztársaság területén át haladt Losonc felé, amely határt a magyar fél lezárta. ${ }^{21} \mathrm{~A}$ résztvevők továbbá megegyeztek egyes feladataikban: létrehoztak egy sajtó-, illetve tájékoztató központot a lakosság információval való ellátásának megsegítésére, egy másik csoport a bánya ügyeivel foglalkozott, míg a harmadik operatív csoport a járás lakosságának élelmiszerrel, üzemanyaggal stb. történő ellátását ellenőrizte. ${ }^{22}$

Augusztus 23-án a JNB tanácsa a járás összes helyi nemzeti bizottságát arra utasította, hogy a lakosokat a helyi hangosbemondón keresztül egyfajta tiltakozó petíció aláíására szólítsák fel, amely elítéli az ország katonai megszállását. ${ }^{23}$ További utasításként gyászlobogó felvonására kötelezték a községeket. Szintén tiltakozó jegyzéket intéztek valamennyi, a megszállásban részt vevő ország nagykövetségéhez.

18 ŠABB-PVK, f. OV KSS VK, ZPr 1968, Zápisnica zo zasadnutia Predsedníctva OV KSS vo VK, 2. september 1968, 8.

19 ŠABB-PVK, f. MNV VK, ZP 1968, Zápisnica 4. mimoriadnej schôdzky pléna MNV vo VK, 24. august 1968. 3.

20 ŠABB-PVK, f. MNV VK, ZP 1968, Zápisnica zo zasadnutia mimoriadnej rady MNV vo VK, 24. august 1968. 2 .

21 ŠABB-PVK, f. OV KSS VK, ZPr 1968, Zápisnica zo zasadnutia Predsedníctva OV KSS vo VK, 21.23. august 1968, 2.

22 ŠABB-PVK, f. OV KSS VK, ZPr 1968, Zápisnica zo zasadnutia Predsedníctva OV KSS vo VK, 21.23. august 1968, 4-5.

23 ŠABB-PVK, f. Spisy 1968, č. 140/1968 
A SZLKP Járási Bizottsága elnökségének augusztus 24-i ülése alkalmával vitatták meg az CSKP rendkívüli XIV. kongresszusának határozatait, amellyel az elnökség teljes egészében egyetértett, majd jóváhagyták a kongresszus nyilatkozatának sokszorosítását, hogy az továbbítva legyen valamennyi járási alapszervezethez. ${ }^{24}$ Ismételten napirendre kerültek a gázolaj hiányára utaló jelek: az eladását korlátozták, valamint felszólították a mezőgazdasági szövetkezeteket, hogy csakis az aratásnál vegyék igénybe a gázolajat. Akadt olyan szövetkezet is, amelyik augusztus 21-töl kezdve öt napon át csupán három-öthordónyi gázolajat kapott, így kénytelenek voltak lemondani a szalmagyüjtésröl, és a tarlóhántás is szünetelt. ${ }^{25}$

Ugyanezen a napon Nagykürtösön a JNB szervezésében egy tömegtüntetésre került sor nagyjából 2000-2500 fő részvételével. Sok ember nagyméretű transzparenst tartott a kezében, amellyel kifejezte, hogy a dubčeki irányvonalat támogatja, a magyar katonákat pedig felszólították, hogy hagyják el a város területét. ${ }^{26}$ Szintén aznap, augusztus 24-én a városi hangosbemondón keresztül Zoltán Pal'ko ismételten nyugalomra intette a város lakóit, valamint magyar nyelven szólította fel a Magyar Néphadsereg alakulatait a távozásra. Sok nagykürtösi lakos egyébként sérelmezte, hogy a párt helyi vezetője egyáltalán magyarul is felszólalt. ${ }^{27}$

Mindeközben a városban állomásozó 31/1. hk. század átcsoportosítást hajtott végre. Augusztus 25-én a szovjet Déli Hadseregcsoport parancsnoka módosította a 8. gl. hadosztály feladatát, miszerint az általuk megszállva tartott terület tovább bővül: létrejött egy újabb helyörség Nagyszombat központtal, míg a nagykürtösi helyörséget bevonták és megszüntették (M. Szabó 2019, 141). A Nagykürtösön állomásozó század ideiglenesen a járásbéli Csáb község kataszteri területének északi részén található bükkfaerdőben telepedett le, majd onnan továbbhaladva Lévára menetelt az egységéhez, hogy ott átvegye a katonai laktanya keleti oldalának ellenőrzését a 31/3. hk. századtól, mert azt a Nyitrai járásbéli Nagylapás községbe telepítették át (Csík 2018, 57-59).

Ezen átcsoportosítások nem jelentették azonban azt, hogy Nagykürtösröl végleg kivonultak volna a megszálló egységek. Ellenörzéseket továbbra is tartottak immár Léváról irányítva, sőt szeptember elején a városba vezényelték a 3. gl. zászlóaljat (M. Szabó 2019, 226). Az egység katonái ismételten a város szélén található domboldalon telepedtek le, majd az alváshoz szalmát kértek a helyi, közelben tartózkodó gazdáktól. Ök - a katonák visszaemlékezései szerint - csúnyán elzavarták őket, majd végül egy idős helybéli segített nekik. A kezdeti feszültség után a közhangulat fokozatosan javult, a tábori konyhában gyakori vendégek voltak a helybéli gyerekek. Az egységet két hét múlva visszarendelték Lévára, ahol szintén a katonai laktanya örzésében vettek részt a továbbiakban (Végh 2008, 36).

A helyi bányában a termelés csak pár napig haladt lassú ütemben, de már augusztus 26-ra napi négyszáz tonna barnaszenet hoztak a felszínre. Augusztus 31-

24 ŠABB-PVK, f. OV KSS VK, ZPr 1968, Zápisnica zo zasadnutia Predsedníctva OV KSS vo VK, 24. august 1968, 2-3.

25 Új Szó, 1968. szeptember 5. 2.

26 ŠABB-PVK, f. ONV VK, ZP 1968, Správa o súčasnej politickej, hospodárskej a zásobovacej situácie v okrese. Priloha zápisnice z mimoriadneho plenárneho zasadnutia ONV vo VK, 27. august 1968. 3. 27 ŠABB-PVK, f. MNV VK, ZP 1968, Zápisnica zo zasadnutia mimoriadnej rady MNV vo VK, 24. august 1968. 2. 
én tartották a „Dubček-müszakot”, melynek keretében csaknem kétezer tonnát termeltek ki, azóta rendszeresen teljesíttették a terveket. ${ }^{28}$ Mivel ipari üzem más nemigen akadt a városban és a járásban, ezért nagy ipari veszteségekről nem lehetett beszélni. A város és a járás vezetői is megértették, hogy a kialakult helyzetből az egyetlen kiút az élet normalizálása - ezt már a SZLKP JB augusztus 27-i plenáris ülésén is helyeselték. ${ }^{29}$

Szintén augusztus 27-én a járási Csemadok nyilatkozatot tett közzé a járás magyar nemzetiségű lakosai nevében, melyben elítélte a megszállást. ${ }^{30}$ Hangsúlyozták, hogy kiállnak Csehszlovákia Kommunista Pártjának Akcióprogramja mellett, és azt a csehekkel és a szlovákokkal együtt fogják megvalósítani, azon népekkel, akikkel már ezer éve együtt élnek. A Varsói Szerződés csapatait pedig felszólították, hogy egységeiket mielőbb vonják ki Csehszlovákia területéről. (Egyébként a járási szervezet megalakulását a Csemadok Központi Bizottsága csak október 20án hagyta jóvá. ${ }^{31}$ )

A JNB ismét csak augusztus 27-én tartotta rendkivüli plenáris ülését, amelyen valamennyi járásbéli község delegáltja is jelen volt. Az ülésen az egyes községi képviselők beszámoltak az elmúlt hét eseményeiről, és sürgették a normalizációt. Szinte minden faluban végig nyugodt maradt a helyzet, semmilyen komolyabb incidensre nem került sor. Inám községben például a lakosság a Budapeströl sugározott rádió adását hallgatta, amelyből megállapították, hogy hamis információkat terjesztettek Csehszlovákiával kapcsolatban. Az ipolynyéki Helyi Nemzeti Bizottsági elnök szerint az országban élö népek elkötelezettebbek lettek, mint valaha. ${ }^{32}$

A járásbéli konszolidáció és normalizáció elindítója a SZLKP JB augusztus 30-i plenáris ülése volt, amelyen az egybegyültek bizalmat szavaztak a SZLKP augusztus 26-28-i rendkívüli kongresszusán első titkárrá választott Gustáv Husáknak ${ }^{33}$ (ez a kongresszus pedig egyben érvénytelenítette a CSKP XIV. kongresszusának határozatait). Ezzel párhuzamosan a lakosság körében olyan információk kezdtek elterjedni, hogy „Dubček és Smrkovský elvtársak már nem sokáig fognak megmaradni saját funkciójukban" (Sikora 2018, 448).

\subsection{A járás a katonai egységek kivonásának idején}

Szeptember első felében került sor Nagykürtösön a SZLKP járási pártaktívájára, ahol az egybegyült párttagok a csehszlovákiai politikai helyzetet tárgyalták meg. Egyetértettek abban, hogy számukra a moszkvai jegyzőkönyvekbe foglaltak teljesítése a legfontosabb, mert csak így normalizálhatják az országot. ${ }^{34} \mathrm{~A}$ járás ak-

28 Új Szó, 1968. szeptember 5. 2.

29 ŠABB-PVK, f. OV KSS VK, ZP 1968, Zápisnica zo zasadnutia pléna OV KSS vo VK, dňa 27. augusta 1968, 4.

30 ŠABB-PVK, f. Spisy 1968, A CSEMADOK Nagykürtösi Járási Elnöksége Nyilatkozata.

31 A Hét, 1968. október 27. 2.

32 ŠABB-PVK, f. ONV VK, ZP 1968, Zápisnica z mimoriadneho plenárneho zasadnutia ONV vo VK,

27. august 1968. 3.

33 ŠABB-PVK, f. OV KSS VK, ZP 1968, Zápisnica zo zasadnutia pléna OV KSS vo VK, dňa 30. augusta 1968, 27.

34 Új Szó, 1968. szeptember 8. 4. 
cióprogramját a megszállás miatt nem tudták időben elfogadni, így azt későbbre halasztották.

Mindeközben egy kisebb kellemetlenségre is sor került: a Pozsonyban kiadott Pravda címü központi szlovák pártlap szeptember 7-i számában egy, a rétsági katonákat lejárató cikk látott napvilágot, ami miatt a rétsági ezred politikai biztosa a nagykürtösi vezetöket szeptember 12-re Lévára rendelte be. A politikai biztos tiltakozott a cikk miatt, amit a nagykürtösi vezetöség tudomásul vett (Solymosi 2018, 72).

Az idő előrehaladtával a járási szerveknek ismételten a járás rossz gazdasági mutatóinak feljavításával kellett foglalkozniuk. Szeptember 13-án a járási pártszerv plenáris ülésén egy nagyjából kétezer személyt foglalkoztató ipari üzem létrehozását indítványozták. ${ }^{35} \mathrm{~A}$ gyülésen fogadták el a járás akcióprogramját is, melynek egyik legföbb célkitüzése a járás központi szervek általi fejletlenné nyilvánitása lett, amely a megvalósulandó beruházásoknak ötven százalékos kedvezményt jelentene. ${ }^{36}$ Ezzel a problémával a Közép-szlovákiai Kerületi Nemzeti Bizottság is csakhamar elkezdett foglalkozni, amely a Szlovák Nemzeti Tanács elnöksége elé terjesztette az ügyet. ${ }^{37}$

Az október 3-i csehszlovák-szovjet tárgyalások eredményeképpen a szovjet Déli Hadseregcsoport elsö ütemben tervezte kivonni a 8. gl. hadosztályt, ugyanakkor a legutolsó magyar csapatok október 31-én hagyták el Csehszlovákia területét - ök voltak a Nagykürtöst is megszálló rétságiak (Pataky 2008, 148-149). Mielött ez megtörtént volna, október 22-én délután a hadosztály politikai biztosa, valamint a 31/1. hk. század parancsnoka, Hábel Péter búcsúlátogatást tettek a járás párt- és állami vezetőinél. A találkozó jó, baráti légkörben folyt le, ráadásul a küldöttséget meg is vendégelték, melynek során a csehszlovákiai helyzetről nyilt eszmecserét folytattak (Solymosi 2018, 99). Látni lehetett, hogy az idő elörehaladtával a lakosság és a megszálló katonaság közötti feszültség ugyan csökkent, de végleg nem szünt meg. Ugyan durva beavatkozásnak tartották a Varsói Szerződés Csehszlovákia elleni katonai intervencióját, belátták, hogy a nyugalom és a higgadt magatartás az egyedüli ,járható út” a helyzet normalizálásához, s végső soron a megszálló erők kivonásához. A csapatok kivonása végül a tervezetteknek megfelelően, október 31-én valósult meg Léváról (Pataky 2008, 149).

Míg a magyar csapatok távoztak az ország területéröl, addig a szovjet egységek egészen a rendszerváltásig maradtak, sőt Nagykürtös közvetlen közelében (ámbár a Zólyomi járásban) is volt pár alakulat. Az Oremov Laz nevezetü katonai körzetben, ahol egy kisebb szovjet lakónegyed is felépült, a szovjet 30. harckocsiezred és a szovjet 144. légelhárító ezred lett elhelyezve, míg a Riečkyn a 20. felderítő zászlóalj, a 75. harckocsizászlóalj és a 901. légelhárító zászlóalj voltak megtalálhatók (Aláč 2020, 63). Az itt állomásoztatott katonák nem egyszer mezőgazdasági munkásokként segitettek a környező, föleg a Nagykürtösi járáshoz tartozó falvak földműves szövetkezeteinek, mint például Száraznyírjes, Nagylám, Dacsólám, Érújfalu (Aláč 2020, 124). A nagykürtösi lakótelepek építéséből is sokszor kivették a részü- 
ket. Hamarosan elkezdték a LIAZ gépkocsigyártó üzem épitését, valamint felépült a nagyzellői - a földgázvezetékben lévő nyomást szabályozó - kompresszorállomás is, továbbá befektetések érkeztek a helyi szőlőtermesztésbe (Paule 1975, 11).

A járás lakossága fokozatosan hozzászokott a közelben állomásoztatott szovjet katonák jelenlétéhez, ami azt is eredményezte, hogy már 1968 őszén az Oremov Laz-i katonákból összeállt futballcsapat barátságos mérkőzéseket játszott a járásbéli Erdőmeg, Szklabonya és Zsély községek csapataival (Aláč 2020, 60).

\section{Összefoglalás}

Csehszlovákiában a prágai tavasznak nevezett időszak lényegében egy reformkísérlet volt az „emberarcú szocializmus” kialakítására. Alexander Dubček reformjai komoly támogatást hoztak a személyének és a pártnak, egy idő után azonban a tömegek szemmel látható módon gyorsítani akarták a folyamatot. Ez viszont aggasztó volt a többi „szocialista testvérpárt” vezetőjének. A változások gyors leállítása és megakadályozása céljából a Varsói Szerződés öt tagállama - köztük Magyarország is - az 1968. augusztus 20-ról 21-re virradó éjszaka során megszállta Csehszlovákiát, az állami- és pártvezetőket pedig a szovjetek Moszkvába hurcolták, ahol az általuk létrehozott rendszer lebontását fogadtatták el velük.

A Nagykürtösi járás épp 1968 szabadabb politikai légkörében alakult meg, részben a Losonci járás nyugatabbra fekvő területeiböl. Azért (is) hozták létre, hogy azt központilag egy kevésbé fejlett régiónak minősítsék le, mivel így nagyobb eséllyel érkezhettek volna ipari befektetések az amúgy is rossz gazdasági mutatókkal rendelkező járásba. A járási szervek közül elsőnek Szlovákia Kommunista Pártja Járási Bizottsága alakult meg, amely már márciusi alakuló közgyülésén a reformok mellett foglalt állást. Viszonylag későn, csak július végén alakult meg a Nagykürtösi Járási Nemzeti Bizottság, amely szintén támogatásáról biztosította az állami vezetést. Több fontos feladat is várta az éppen csak megalakult járási szerveket: az ország egyik legújabb közigazgatási egységének kellett valamennyi infrastruktúráját megszervezni, kiépíteni. E teendőiket azonban félbeszakitotta a Csehszlovákia ellen indított 1968. augusztus 21-i katonai intervenció.

A prágai tavasz végzetét megpecsételő Duna-hadművelet keretében a Nagykürtösi járás területét föleg a Magyar Néphadsereg zalaegerszegi 8. gépkocsizó lövészhadosztálya alá rendelt rétsági 31. harckocsiezred szállta meg. A „rétságiak” feladata az volt, hogy Nagykürtös központtal egy helyörséget hozzanak létre. Ezt a feladatukat sikerrel véghez is vitték, bár a nagykürtösi helyőrség alig négy nap után, augusztus 25-én megszünt, s területét hozzácsatolták a lévai helyőrséghez. Innét kezdve az egyes őrjáratokat már kizárólag a stratégiai szempontból is fontosabb Léváról irányították egészen a megszállás végéig.

A megszállás ténye az itt élő szlovák és magyar lakosságot sokként érte: az első napokban Nagykürtösön a megszálló csapatok elleni tüntetésekre került sor több ezer fő részvételével. A katonák által osztogatott propagandisztikus röplapokat nyilvánosan tépték szét vagy égették el. Az üzemekben, valamint több községben a megszállást elítélő tiltakozó petíciók aláirására nyilt lehetőség. A kezdeti feszült- 
ség az idő múlásával fokozatosan enyhült, a sztrájkok egyre ritkábbak lettek, a termelésben tapasztalható ideiglenes csökkenést pedig az ún. Dubček-müszakra keresztelt túlórázásokkal kompenzálták. A járás hivatalos szervei a megszállás ideje alatt végig a nyugalom megőrzésére, a megszállók ignorálására szólították fel a lakosságot. Együttmüködni a Magyar Néphadsereggel csakis a rend és a közbiztonság fenntartása érdekében voltak hajlandók. Ez az együttmüködés - mondhatni - eredményes volt, hiszen komolyabb, illetve halálos kimenetelű incidensre sehol sem került sor a helyörség területén.

Az ország katonai megszállása egészen 1991-ig tartott, de a magyar csapatokat már 1968 októberében, az ún. első lépcsőben kivonták az országból: utolsónak épp a lévai helyőrséget „fenntartó” rétsági 31. harckocsiezred hagyta el Csehszlovákiát (október 31.). Mielött kivonultak volna, az ezred vezetöi Nagykürtösön is búcsúlátogatást tettek a járási elöljáróknál. A búcsúzás viszont már szivélyes „elvtársi” légkörben zajlott, ami lényegében a fokozatosan létrejövő konszolidációnak tudható be.

A prágai tavasz eltiprásának Nagykürtösi járásbéli „lefolyása” lényegében alig mutatott eltérést az ország más pontjain tapasztalható jelenségektöl: a kezdeti felfordulást mindenhol fokozatosan felváltotta a lakosság kényszerü ,beletörődése” az új helyzetbe. Az egyetlen apró, de mégis jelentős különbség viszont az volt, hogy többek közt - e járásba nem a szovjet, hanem magyar katonai erők érkeztek, 1938 után immár másodízben. Igaz, 1968-ban egy merőben más ideológiai alapon álló hadsereg lépte át az államhatárt, és a helybéliek - még a magyarok - sem fogadták őket „,virágesővel” és ácsolt diadalkapukkal.

\section{Források és irodalom}

\section{Levéltári források}

Štátny archív v Banskej Bystrici, pobočka Vel'ký Krtíš (ŠABB-PVK)

fond Mestský národný výbor, zápisnice Pléna 1968 (f. MNV VK, ZP 1968)

fond Mestský národný výbor, zápisnice Rady 1968 (f. MNV VK, ZR 1968)

fond Okresný národný výbor vo Vel'kom Krtiši, zápisnice Pléna 1968 (f. ONV VK, ZP 1968)

fond Okresný národný výbor vo Vel'kom Krtiši, zápisnice Rady 1968 (f. ONV VK, ZR 1968)

fond Okresný výbor Komunistickej strany Slovenska vo Vel'kom Krtiši, zápisnice Pléna 1968 (f. OV KSS VK, ZP 1968)

fond Okresný výbor Komunistickej strany Slovenska vo Vel'kom Krtiši, zápisnice Predsedníctva 1968 (f. OV KSS VK, ZPr 1968)

fond Spisy 1968 (f. Spisy 1968) 


\section{Publikált források}

Csík Ádám Lajos (2018): Az 1968-as csehszlovákiai bevonulás a 31. harckocsiezred összefoglaló jelentése alapján. Szeged: JATEpress.

Solymosi József szerk. (2018): „Zala” 1968. A Magyar Néphadsereg 8. gépkocsizó lövészhadosztály hadmüveleti naplója Csehszlovákia megszállásának időszakából. Budapest: HM Hadtörténeti Intézet és Múzeum.

\section{Szóbeli források}

Interjú Miskei Margit csábi lakossal, 2020. december 1. A beszélgetés digitalizált változata a szerző tulajdonában.

\section{Korabeli sajtó}

A Hét, 1968.

Smer, 1968.

Új Szó, 1968.

\section{Szakirodalom}

Aláč, Ján (2020): Sovietski vojaci na juhu stredného Slovenska 1968-1991. Novohradský historický spolok.

Benický, Karol (1977): Okres Vel'ký Krtíš. Martin: Vydavatel'stvo Osveta.

Békés Csaba (2008): Kádár János és a Prágai Tavasz. Beszélő 13/7, 15-36.

Békés Csaba (2008): Kádár János és az 1968-as csehszlovákiai válság. In: Évkönyv 2008. Közelítések a Kádárizmushoz. Szerk. Germuska Pál - Rainer M. János. Budapest: 1956os Intézet, 190-228.

Bencsik Péter (2016): Csehszlovákia története dokumentumokban. Budapest: Napvilág Kiadó.

Berend T. Iván (1999): Terelőúton. Szocialista modernizációs kísérlet Közép-és Kelet-Európában 1944-1990. Budapest: Vince Kiadó.

Boros Ferenc (2003): 1968 és a kádári politika. Fórum Társadalomtudományi Szemle 5/1, 79-97.

Homor György (2010): Hívatlan vendégként északi szomszédainknál. 1968. Pápa: Jókai Mór Városi Könyvtár.

Horváth Attila (2001): A Csehszlovákia 1968-as megszállásában résztvevő Magyar Katonai Kontingens utánszállitási tapasztalatai. Katonai Logisztika 9/3, 228-238.

Jagadics Péter (2018): 1968. Egy elfelejtett hadjárat. A zalaegerszegi 8. gépkocsizó lövészhadosztály és a katonai elhárítás részvétele Csehszlovákia megszállásában. Gencsapáti: Szülöföld Könyvkiadó.

Kořínek, Otakar (2006): Pozývací list 1968. Bratislava: Albert Marenčin - Vydavatel'stvo PT. Kun Miklós (2008): A prágai tavasz titkos története. Budapest: Akadémiai Kiadó.

M. Szabó Miklós (2019): A Magyar Néphadsereg és a Varsói Szerződés csapatainak részvétele Csehszlovákia megszállásában. Budapest: Dialóg Campus. 
Mitrovits Miklós (2012): Kádár és Dubček 1968-ban. In: Kádár János és a 20. századi magyar történelem. Tanulmányok. Szerk. Földes György - Mitrovits Miklós. Budapest: Napvilág Kiadó, 125-146.

Mitrovits Miklós (2018): Út a katonai intervencióhoz. A prágai tavasz és a magyar pártvezetés. Világtörténet $8 / 3,415-443$.

Pataky Iván (2009): A Magyar Néphadsereg és Dél-Szlovákia lakosságának kapcsolata Csehszlovákia 1968. évi megszállása idején. Fórum Társadalomtudományi Szemle 11/2, 109-121.

Pataky Iván (1997): A Magyar Néphadsereg közremüködése Csehszlovákia 1968. évi megszállásában. Hadtörténelmi Közlemények, 110/2, 355-387.

Pataky Iván (2008): A vonakodó szövetséges. A Magyar Néphadsereg közremüködése Csehszlovákia 1968. évi megszállásában. Budapest: Rastafari BT.

Paule, Ladislav (1975): Okres Vel'ký Krtíš a okolie. Martin: Osveta.

Popély Árpád (2006): A (cseh)szlovákiai magyarság történeti kronológiája 1944-1992.

Somorja: Fórum Kisebbségkutató Intézet.

Sikora, Stanislav (2018): Szlovákia a prágai tavasz után. Változások a Szlovák Kommunista Pártban és a szlovák társadalomban, 1968. augusztus - 1969. április. Világtörténet 8/3, 445-469.

Vajda Barnabás (2020): Hidegháború és európai integráció. Második, módositott szövegü kiadás. Komárom: SJE Tanárképző Kar.

Vajda Barnabás (2017): A csehszlovákiai ideológiai harc természetéről (1948-1989). Komárom: Selye János Egyetem Tanárképzö Kara.

Vajda, Barnabas et al. (2016): Forms of Political and Media Propaganda in Central Europe, Czecho-Slovakia and Hungary (1938-1968). Komárom: Selye János Egyetem Tanárképző Kara.

Végh József (2008): Amiröl negyven éven át nem beszéltünk. Honismeret 36/5, 31-40.

\section{Képmelléklet:}

1. sz. kép - A föbb hadmüveletek a Nagykürtösi járás területén. Forrás: google.com/maps - a szerző által szerkesztve.

2. sz. kép - A 31/1. hk. e. táborának viszonylagos elhelyezkedése Nagykürtösnél. A város 1968-ban ugyan kisebb területü volt, de a beépített déli határa mindmáig változatlan maradt. Forrás: earth.google.com - a szerző által szerkesztve.

3. sz. kép - Nagykürtösi pillanatkép 1968. augusztus 21-én. A magyar csapatok mindvégig a város déli határában elterülö domboldalon állomásoztak. Forrás: www.velky-krtis.sk (letöltve: 2021. június 5.) 

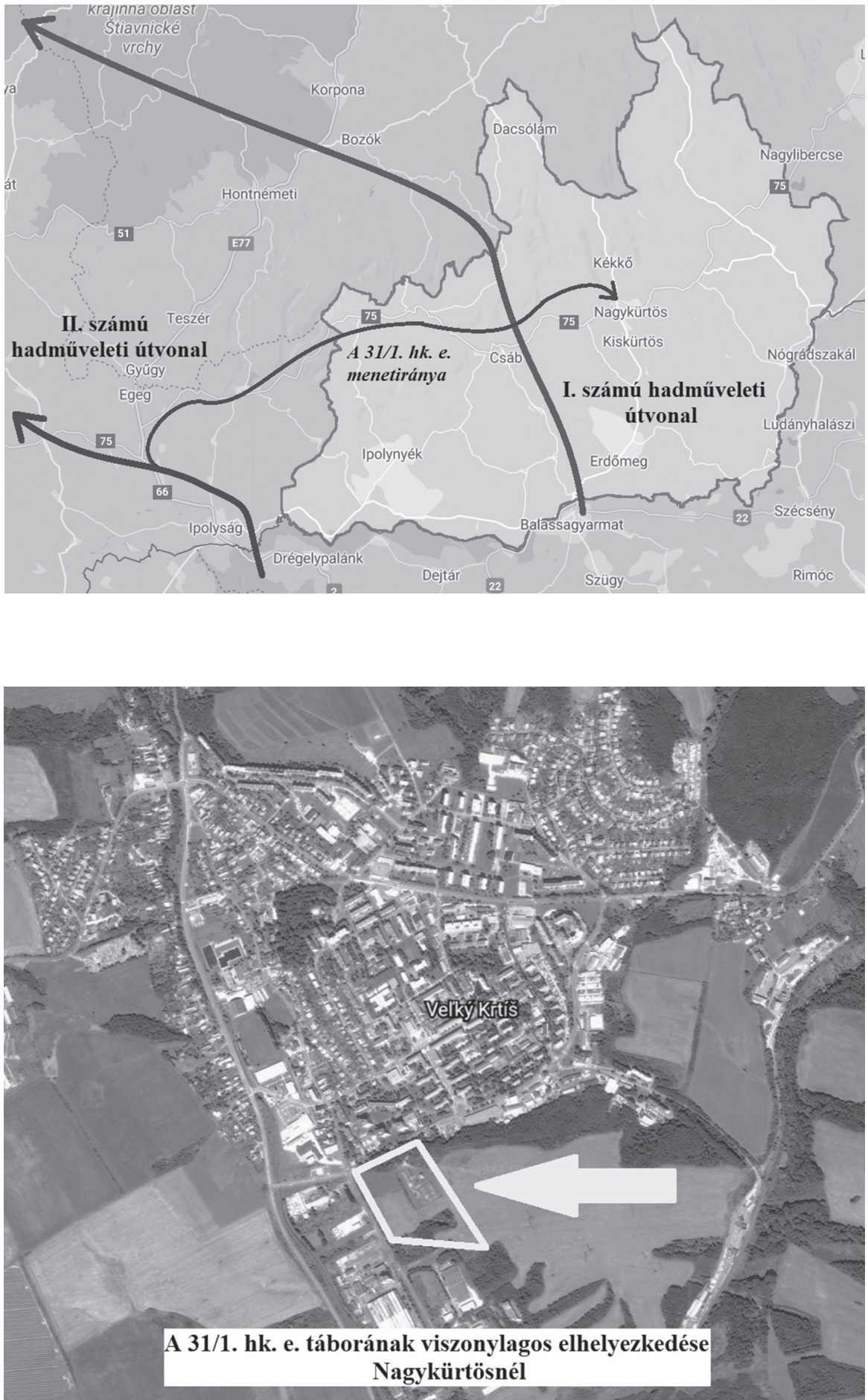


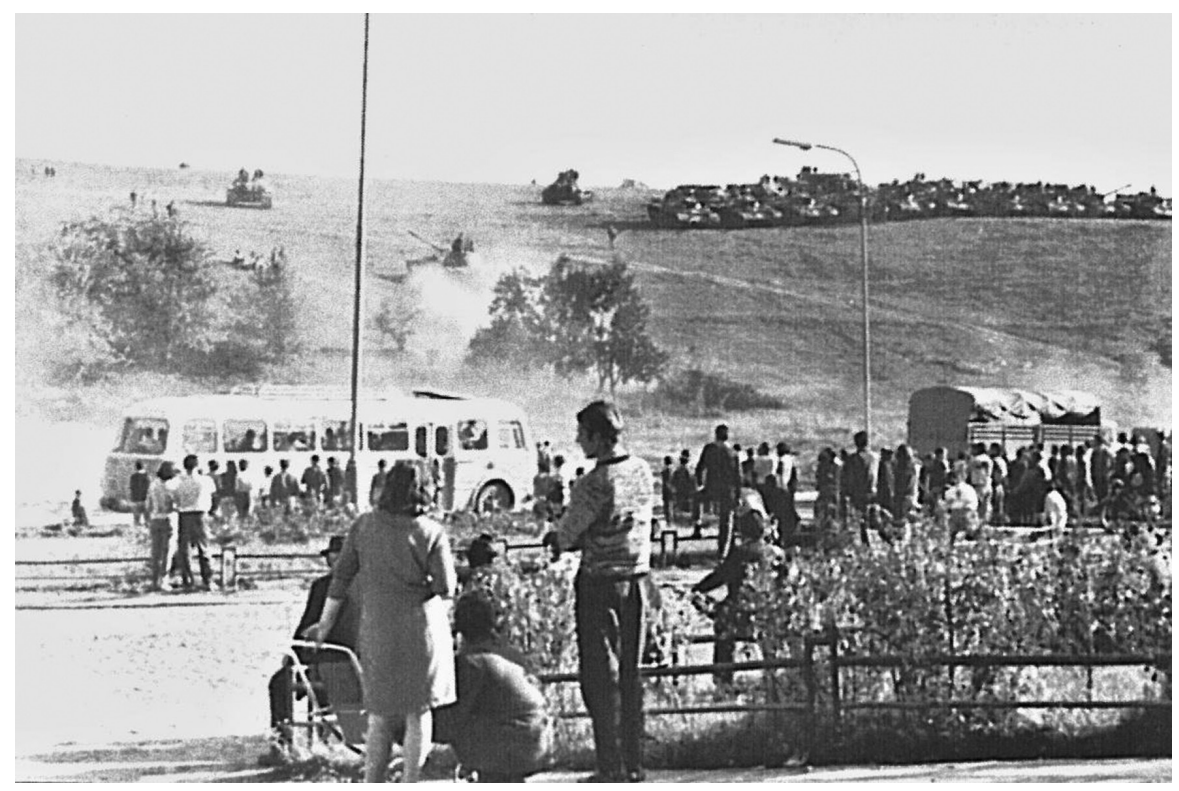

